\title{
Hepatoprotective Effects of Pig Placental Hydrolysates on Liver Damage- induced Rats by Injecting Carbon Tetrachloride
}

\author{
Sun Young Park $\cdot$ Da Sol Kim $\cdot$ Suna Kang $\cdot$ Sunmin Park
}

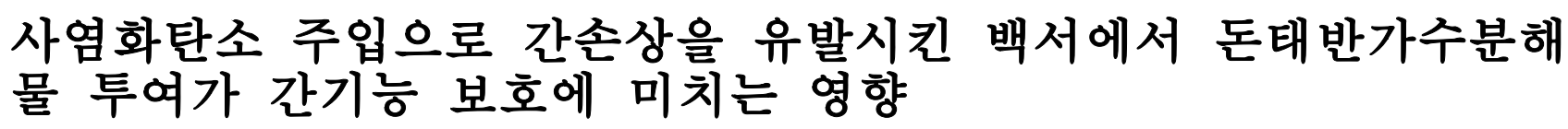

박선영 · 김다솔 · 강선아 · 박선민

Received: 19 April 2012 / Accepted: 29 May 2012 / Published Online: 30 June 2012

(C) The Korean Society for Applied Biological Chemistry 2012

\begin{abstract}
The aim of this study was to determine hepatoprotective effects of pig placenta hydrolysates (PLA) on liver damageinduced rats. Sprague Dawley rats were subcutaneously injected with carbon tetrachlorides and divided into 4 groups: negative control (DMSO treated), two PLA treated groups, low dosage of PLA (LPLA; $300 \mathrm{mg} / \mathrm{kg}$ body weight) and high dosage of PLA (HPLA; $1000 \mathrm{mg} / \mathrm{kg}$ body weight), and silymarin treated group ( $80 \mathrm{mg} / \mathrm{kg}$ body weight). Rats in each group orally received assigned compounds for 3 weeks. For the normal control group vehicle (corn oil) was injected. After 3 weeks, liver and spleen weights were greater in the two PLA and silymarin groups than the negative control group. After bromosulfalein (BSP) treatment, the clearance rates were in the descending order of negative control $>$ LPLA $>$ HPLA $=$ silymarin and serum BSP levels exhibited the opposite trends of the clearance rates. Serum levels of aspartate aminotransferase, alanine aminotransferase, triglyceride, and cholesterol lowered with PLA in a dose-dependent manner. The decrease with HPLA was similar to that with silymarin. In addition, triglyceride, cholesterol, lipid peroxides levels in the liver decreased in HPLA and silymarin compared to the negative control. The liver morphometry was improved in HPLA- or silymarin-treated rats in comparison to the negative control. In conclusion, HPLA administration ameliorated the hepatotoxicity as much as silymarin in rats injected with carbon tetrachlorides.
\end{abstract}

D. S. Kim $\cdot$ S. Kang $\cdot$ S. Park $(\triangle)$

Dept of Food and Nutrition, Hoseo University, Asan, Chungnam-Do 336795, Repulic of Korea

E-mail: smpark@hoseo.edu

S. Y. Park

Codebio Co. Ltd, Cheonan, Chungnam-Do 331-815, Repulic of Korea
Keywords bromosulfalein · carbon tetrachlorides $\cdot$ liver damage $\cdot$ pig placenta $\cdot$ triglyceride

서 론

인간의 신체 장기 중 간은 생체 내 다양한 대사가 활발하게 일 어나는 장기로서, 지방 성분이 포함된 음식이나 알코올의 과다 섭취, 바이러스의 감염, 각종 약품과 같은 유해물질, 영양부족 등 다양한 원인에 의해 급성 또는 만성의 장애가 일어날 수 있 다. 또한, 간은 우리 몸에 독성 물질에 노출될 때 제거하는 중 추적인 역할을 하는 기관으로 독성물질에 의해 손상될 가능성 이 높다. 간 세포의 손상은 독성 물질을 제거하는 해독기능에 장애를 나타내고, 면역체계에 이상을 가져와 지방간, 간염, 황 달, 간경화, 간암 등을 야기시킬 수 있다(Mansour 등, 2006; Jo 등, 2008). 최근에는 비만인에서 비알코올성 지방간의 발생이 증가하는데(Chiang 등, 2011), 이것은 식생활과 생활습관의 서 구화로 인해 비만 인구가 증가와 밀접한 관련이 있다. 또한 알 코올 섭취의 지속적인 증가, 비만 및 스트레스 등을 감안하면 지방간을 비롯한 간질환의 발병이 급증할 것으로 사료된다. 간 질환의 치료 방법은 식이 요법과 약물 요법이 있으며 약물 요법 으로 사용하는 것으로 우루소데옥시콜린산(ursodeoxycholic acid), 실리마린(silymarin), biphenyl dimethyl dicarboxylate (DDB), 글 루타치온(glutathione), 글리시리진(glycyrrhizin) 등과 같은 간 세 포 재생촉진제 및 간 기능 보조제, 아시클로바(acyclovir)와 같 은 항바이러스제 등의 약물이 사용되고 있다(Abdel-Hameid, 2007; Korenaga 등, 2011; Rašković 등, 2011; Chen 등, 2012).

혈액 융모막으로 구성되어 있는 태반은 태아와 모체조직 사 이에 접촉을 유지하면서 태아에게 필요한 산소 및 영양소 공급 과 태아가 생성하는 노폐물을 제거하는데 중요한 역할을 한다. 
태반에는 태아의 성장에 필요한 다양한 영양 물질과 호르몬 등 을 함유하고 있어서 태반(인태반, 돈태반, 양태반 등)은 태아뿐 아니라 성인 특히 갱년기 증상 완화, 간 기능의 개선 및 미용 목적 등을 위해 광범위하게 사용되고 있으나 태반 추출물의 효 과에 대한 의학적인 근거는 적다 $(\mathrm{Pal}$ 등, 1995 ; Lui 등, 1998 ; Jung 등, 2011). 병원에서는 태반 추출물을 주사제로 사용하고 있어서 많은 연구가 필요하며 돈태반 같은 경우 주사제보다는 경구 투여제로 사용하는 것이 오남용이나 부작용을 방지할 수 있다. 인터넷 등에서 태반 추출물이 간 손상 보호 효과가 있다 는 광고들은 많으나 아직까지 돈태반의 경구 투여가 간 기능 개선에 효과적인지에 대한 과학적 연구는 적다. 그러므로 본 연 구의 목적은 사염화탄소로 간손상을 유발시킨 백서에서 돈태반 가수분해물의 경구 투여가 간 손상 보호 및 개선 효과가 있는 지를 조사하는 것이다.

\section{재료 및 방법}

재료. 본 실험에서 사용된 돈태반 가수분해물은 (주)코드바이오 (한국)에서 제조한 것을 사용하였다. 돈태반 가수분해물은 단백 질 가수분해 효소인 파파인, 브로멜라인, 프로나아제 및 알칼라 아제로 가수분해한 후 여과단계를 거쳐 지질을 제거하고 멸균 한 후 $\mathrm{pH}$ 를 6.0-7.5로 조절한 제품으로 본 실험에서는 액상의 제품을 동결건조하여 사용하였다.

실험동물 사육. 본 연구에 사용된 동물은 7주령 수컷 Sprague Dawley rat(중앙동물, Korea)을 구입한 후 2주 동안 새로운 사 육 환경에 적응시키고, 실험 전 기간 동안 실험동물들은 고형 사료(대한바이오링크, Korea) 및 물을 자유롭게 섭취시켰다. 사 육실 온도는 $20 \pm 2^{\circ} \mathrm{C}$, 상대습도는 $65 \pm 5 \%$ 를 유지하고, 광주기와 암주기를 12 시간이 되도록 빛을 조절하였다. 모든 실험은 호서 대학교 동물 윤리위원회에서 사전 승인을 받고 진행하였다.

돈태반 추출물 투여. 실험 동물을 체중에 따라 난괴법 (Randomized complete block design)에 의해서 한 군에 8 마 리씩 5 군으로 나누어 사육하였으며 그 중에서 4 군은 사염화탄 소를 주입하여 간 손상을 유발하였다. 간 손상을 유발시킨 백 서가 포함되어 있는 4 군은 무작위로 사염화탄소 + 용매(음성대 조군), 사염화탄소 $+\operatorname{silymarin(ㅇㅑㅇㅅㅓㅇㄷㅐㅈㅗㄱㅜㄴ),~ㅅㅏㅇㅕㅁㅎㅘㅌㅏㄴㅅㅗ~}+$ 저용량 돈태반(저용량돈태반군)과 사염화탄소 + 고용량돈태반(고용량돈 태반군)를 정하였다. 나머지 한군은 정상대조군으로 사염화탄소 를 녹인 용매만을 주입하여 간손상을 유발시키지 않았고 이들 은 투여할 물질을 녹인 용매(vehicle)를 투여하였다.

간 손상을 유발시키기 위해서 사염화탄소(Sigma-Aldrich Chemical Co., USA)를 옥수수유 (CJ 제일제당, Korea)에 1:1로 희석하여 희석액을 $2 \mathrm{~mL} / \mathrm{kg}$ 체중씩 주3회 피하주사하였다. 사염화탄소 주 입이 끝난 다음 날부터 백서는 정해진 물질을 투여하였다. 저 용량과 고용량 돈태반군은 용매(vehicle)에 녹인 돈태반 가수분 해물을 $300 \mathrm{mg} / \mathrm{kg}$ 체중/일 또는 $1,000 \mathrm{mg} / \mathrm{kg}$ 체중/일로 투여하 였다. 음성대조군은 용매(vehicle)인 $\mathrm{DMSO}$ 를 첨가한 생리식염 수를 투여하였고 양성대조군은 silymarin $(80 \mathrm{mg} / \mathrm{kg}$ 체중/일; Sigma-Aldrich Chemical Co.)을 DMSO에 녹인 후 생리식염수 에 희석시켜 투여하였다. 모든 군의 백서는 3주 동안 정해진 군 에 맞추어 물질을 존대를 사용하여 매일 투여하였다. 약물 투여 종료 후 12시간 동안 절식 후에 혈액을 채취하고, ketamin과 xylazine (100 and $10 \mathrm{mg} / \mathrm{kg}$ 체중)으로 마취시키고 Bromosulfalein
(BSP) clearance 실험을 하였다. 실험 후 장기를 채취하여 -70 ${ }^{\circ} \mathrm{C}$ 에 보관하고 분석하였다. 매주 12 시간 금식시키고 꼬리에서 혈액을 채취한 후 혈액을 방치하여 응고시키고, $3000 \mathrm{rpm}$ 에서 10 분간 원심분리하여 혈청을 분리하였다.

BSP clearance 측정. 약물 투여 종료 후에 백서의 $\mathrm{BSP}$ clearance test를 실시하였다(West, 1989). 12시간 금식 후에 백 서를 ketamin과 xyalzin으로 마취한 후 복강을 개복하고 복강 정맥으로 $1 \% \mathrm{BSP}(1 \mathrm{~mL} / \mathrm{kg}$ 체중)을 주입한 후 $1,21,46$ 분에 descending aorta로부터 혈액을 채취하였다. 채취한 혈액에서 혈 청을 분리한 후 혈청에 생리식염수와 $10 \% \mathrm{HCl}$ 용액을 넣고 혼 합하고 산을 중화시키기 위해서 $10 \% \mathrm{NaOH}$ 를 혼합하였다. 혼 합 후 원심분리하고 상등액을 취하여 spectrophotometer 575 $\mathrm{nm}$ 에서 흡광도를 측정하였다. BSP 표준 용액을 농도 단계별로 희석한 후 희석된 $\mathrm{BSP}$ 를 채취한 혈액과 같은 방법으로 처리하 여 흡광도를 측정하였다. BSP 표준적정선으로부터 혈액 샘플의 $\mathrm{BSP}$ 농도를 측정하여 혈액으로부터 $\mathrm{BSP}$ clearance 정도를 측 정하였다. $\mathrm{BSP}$ 청소율은 시간별로 $\mathrm{BSP}$ 가 혈액에서 없어지는 제거율로 계산하였다.

간 손상 지표. 약물 투여 종료 후에 간 손상의 지표로 사용되 는 alanine aminotransferase (ALT)와 aspartate aminotransferase (AST)의 농도를 ALT와 AST kit(아산제약, Korea)를 사용하여 비색정량으로 계산하였다. 또한, 혈청 중성지방과 총콜레스테롤 의 농도(아산제약)를 측정하였다.

간의 지방 및 과산화물 함량. 약물 투여 종료 후에 간에 저장 된 중성지방의 함량을 chloroform-methanol $(2: 1, \mathrm{vol} / \mathrm{vol})$ 로 추 출한 후 chloroform에 녹이고 이것을 $0.1 \%$ triton X-100을 녹 인 PBS 용액에 용해시킨다. 이 용액의 중성지방 함량을 중성 지방 $\mathrm{kit}$ (아산제약)로 비색정량하여 측정한다(Sebokova 등, 1993). 간에 총콜레스테롤함량은 Richmond (1976)의 방법으로 측정하였다. 또한, 간 조직의 과산물의 함량은 Buege와 Aust방 법(1978)으로 thiobarbituric acid reactive substance (TBARS) 를 측정하여 정하였다.

간 조직 형상. 3 주 동안 각군에 따라 약물을 투여한 후에 간을 채취하고, 간 조직의 일부는 $10 \%$ formalin에 고정한 후 일반적 으로 사용하는 조직처리과정을 거쳐 파라핀 포매를 하였다. 포 매한 간 block은 마이크로톰으로 $4 \mu \mathrm{m}$ 으로 조직 절편을 만들었 다. 이 간 조직 절편은 hematoxylin \& eosin 염색 방법에 의해 서 염색한 후 조직의 형상(morphology)을 관찰하였다.

통계 처리. 결과는 평균 \pm 표준 편차(SD)로 표시하였다. 정규성 통계분석을 하여 각각의 변수들이 정규성을 가진다는 것을 확인 하였다. 간 손상을 유발한 군들에서 각각의 처리군 사이의 변수 들의 통계적 유의성은 one-way analysis of variance (ANOVA) 로 검증하였다. 각 군의 평균값 사이의 차이는 Tukey 방법으로 multiple comparison을 수행하여 결정하였다. 정상대조군인 사염 화탄소를 주입하지 않은 군과 사염화탄소를 주입한 군사이의 통 계적 유의성은 two-sample t-test로 검증하였다. 모든 통계 처리 의 유의성 검증은 $p<0.05$ 로 정하였다.

\section{결 과}

체중 및 장기 무게. 정상대조군에 비해 음성대조군의 백서에서 체중과 epididymal fat pads의 양은 감소하였고, silymarin이나 돈태반 추출물을 투여한 것은 체중이나 epididymal fat pads의 
Table 1 Body weight and weight of organs at the end of experiment

\begin{tabular}{lccccc}
\hline & $\mathrm{CCl}_{4}+$ vehicle & $\mathrm{CCl}_{4}+\mathrm{LPLA}$ & $\mathrm{CCl}_{4}+\mathrm{HPLA}$ & $\mathrm{CCl}_{4}+$ silymarin & $\mathrm{Normal} \mathrm{control}$ \\
\hline Body weight $(\mathrm{g})$ & $214.8 \pm 8.8$ & $214.7 \pm 13.9$ & $207.2 \pm 10.6$ & $218.6 \pm 18.4$ & $237.3 \pm 20.2^{\dagger}$ \\
Epididymal fat pads (g) & $3.8 \pm 0.5$ & $3.7 \pm 0.4$ & $3.7 \pm 0.5$ & $3.6 \pm 0.6$ & $4.4 \pm 0.6^{\dagger}$ \\
Liver (g) & $9.61 \pm 0.16$ & $10.19 \pm 0.81$ & $9.65 \pm 0.80$ & $10.30 \pm 0.92$ & $10.30 \pm 1.25$ \\
Liver (\% of body weight) & $4.28 \pm 0.1^{\mathrm{b}}$ & $4.74 \pm 0.14^{\mathrm{a}}$ & $4.68 \pm 0.47^{\mathrm{a}}$ & $4.71 \pm 0.32^{\mathrm{a}}$ & $4.30 \pm 0.19$ \\
Spleen (g) & $0.63 \pm 0.02$ & $0.68 \pm 0.04$ & $0.64 \pm 0.06$ & $0.68 \pm 0.08$ & $0.64 \pm 0.08$ \\
Spleen (\% of body weight) & $0.29 \pm 0.01^{\mathrm{b}}$ & $0.32 \pm 0.01^{\mathrm{a}}$ & $0.31 \pm 0.03^{\mathrm{a}}$ & $0.31 \pm 0.03^{\mathrm{a}}$ & $0.27 \pm 0.01^{\dagger}$ \\
\hline
\end{tabular}

${ }^{\mathrm{a}, \mathrm{b}}$ Means with different superscripts were significantly different among $\mathrm{CCL}_{4}$-treated groups at $p<0.05$.

'Significant difference between the $\mathrm{CCl}_{4}+$ vehicle group at $p<0.05$.

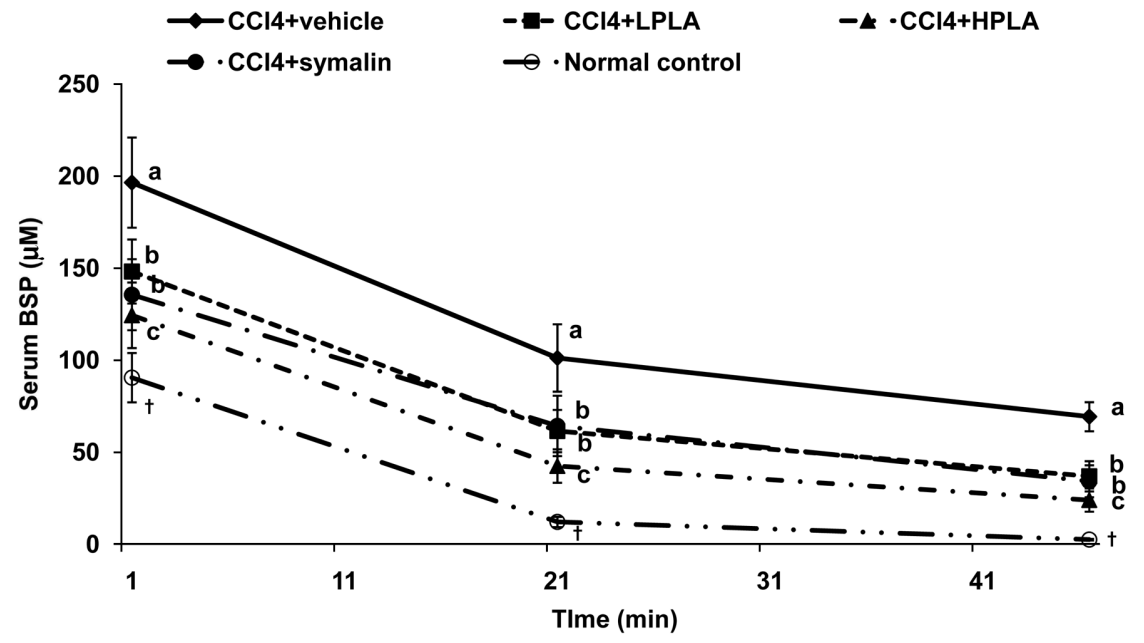

Fig. 1 Clearance rates of bromosulfalein (BSP) at the end of experiment. Liver damage-induced rats by subcutaneously injecting BSP were orally administered with vehicle (saline dissolved with DMSO) for control group, 300 and $1000 \mathrm{mg}$ pig placental extracts/kg bw for low and high dosage groups, respectively, and $80 \mathrm{mg}$ silymarin/ $\mathrm{kg}$ bw for positive control in a daily basis. Normal rats were treated with vehicle as a normal-control group. After 3 weeks of treatment, BSP $(0.01 \mathrm{~g} / \mathrm{kg}$ bw) was injected into abdominal vein clearance and serum BSP levels measured in the blood from descending aorta at 0,21 , and 46 min after injecting BSP. ${ }^{\mathrm{a}, \mathrm{b}, \mathrm{c}}$ Means with different superscripts were significantly different among $\mathrm{CCL}_{4}$-treated groups at $p<0.05$. 'Significant difference between the control $\left(\mathrm{CCl}_{4}+\right.$ vehicle) group at $p<0.05$.

양에 영향을 미치지 않았다(Table 1). 장기 중 사염화탄소에 의 해서 영향을 받을 가능성이 있는 간과 비장의 무게를 비교해보 면 절대 질량과 체중 대비 간의 질량은 정상대조군과 음성대조 군 사이에 차이가 없었지만 체중 대비 지라의 질량 비율은 정 상대조군에 비해 음성대조군에서 더 높았다(Table 1). 사염화탄 소를 투여한 백서에서 체중대비 간과 지라의 비율은 음성대조 군에 비해 양성대조군(silymarin 투여)과 저용량과 고용량 돈태 반추출물의 투여군에서 높았다.

간 손상 정도. $\mathrm{BSP}$ clearance test는 $\mathrm{BSP}$ 를 주입한 후에 제거 율을 측정하는 실험으로 간 기능을 나타내는 지표로 사용될 수 있다. $\mathrm{BSP}$ 는 투여 1 분째에 혈중 농도가 가장 높게 나타났으며 그 후 21분과 46분에 지속적으로 감소하였다(Fig. 1). 정상대조 군에서는 46 분에는 주입한 $\mathrm{BSP}$ 의 $98.8 \%$ 가 제거된 것으로 보 아 간의 기능이 정상적일 경우에 $\mathrm{BSP}$ 는 50 분 이내에 모두 제 거한다는 것을 알 수 있었다. 사염화탄소로 간 손상을 유발시 킨 백서에서는 $\mathrm{BSP}$ 의 제거율이 현저하게 감소하였으며 silymarin, 저용량과 고용량 돈태반 가수분해물은 $\mathrm{BSP}$ 의 제거율 을 현저하게 증가시켰으나 정상대조군의 BSP 제거율 만큼 높 지는 않았다(Table 2).

간세포의 손상 정도를 나타내는 지표인 혈청 ALT와 AST의
농도의 변화를 살펴보면, 정상대조군에 비해 1주차에 혈청 ALT 와 AST의 농도가 가장 높았으며 그 후 점차 낮아지는 경향을 나타내었다(Fig. $2 \mathrm{~A}$ 와 B). 정상 백서에 비해 간 손상을 유발시 킨 백서에서 혈청 AST와 ALT 농도가 높았다. 간 손상을 유발 시킨 백서에서 이 효소들의 혈청 농도는 silymarin의 투여에 의 해서 낮아졌으며 돈태반 가수분해물의 투여시 농도 의존적으로 낮아졌다(Fig. 2A와 B). 약물 투여 3주째에 고용량 돈태반군의 혈청 $\mathrm{AST}$ 농도가 거의 정상대조군과 유사한 값을 나타내었다 (Fig. 2B).

혈청과 간의 TBARS, 중성지방과 콜레스테롤 농도. 사염화탄소 로 간 손상을 유발시킨 백서에서 체내 지방대사 장애가 나타났 다. 정상대조군에 비해 음성대조군에서 혈청 중성지방과 콜레스 테롤 농도가 높아졌으며, 돈태반 가수분해물과 silymarin의 투여 는 농도 의존적으로 혈청 중성지방과 콜레스테롤 농도를 음성대 조군에 비해 저하시켰다(Table 2). 정상대조군에 비해 음성대조 군의 백서의 간에 저장된 중성지방과 콜레스테롤의 양이 증가하 였고, 그 저장양은 돈태반 가수분해물과 silymarin의 투여에 의 해서 감소하였다. 간에 존재하는 과산화물을 나타내는 지표인 TBARS의 함량은 정상대조군에 비해 음성대조군에서 현저히 증 가하였고, silymarin과 돈태반군에서 소폭 감소하였다(Table 2). 
Table 2 Clearance rates of bromosulfalein (BSP) at the end of experiment

\begin{tabular}{lccccc}
\hline & $\mathrm{CCl}_{4}+$ vehicle & $\mathrm{CCl}_{4}+\mathrm{LPLA}$ & $\mathrm{CCl}_{4}+\mathrm{HPLA}$ & $\mathrm{CCl}_{4}+$ symalin & $\mathrm{Normal}^{\mathrm{c}}$ control \\
\hline Total BSP clearance (\%) & $65.4 \pm 8.1^{\mathrm{b}}$ & $81.6 \pm 9.6^{\mathrm{a}}$ & $88.0 \pm 16.1^{\mathrm{a}}$ & $82.9 \pm 13.6^{\mathrm{a}}$ & $98.8 \pm 17.9^{\dagger}$ \\
BSP clearance at 1-21 $\min (\%)$ & $48.5 \pm 8.8^{\mathrm{b}}$ & $58.5 \pm 10.9^{\mathrm{a}}$ & $65.8 \pm 14.1^{\mathrm{a}}$ & $52.6 \pm 13.4^{\mathrm{b}}$ & $86.6 \pm 20.0^{\dagger}$ \\
BSP clearance at 21-46 $\min (\%)$ & $31.5 \pm 3.6^{\mathrm{b}}$ & $40.0 \pm 8.9^{\mathrm{a}}$ & $43.5 \pm 11.4^{\mathrm{a}}$ & $46.8 \pm 11.9^{\mathrm{a}}$ & $79.3 \pm 12.7^{\dagger}$ \\
\hline
\end{tabular}

${ }^{\mathrm{a}, \mathrm{b}}$ Means with different superscripts were significantly different among $\mathrm{CCL}_{4}$-treated groups at $p<0.05$.

${ }^{\dagger}$ Significant difference between the $\mathrm{CCl}_{4}+$ vehicle group at $p<0.05$.

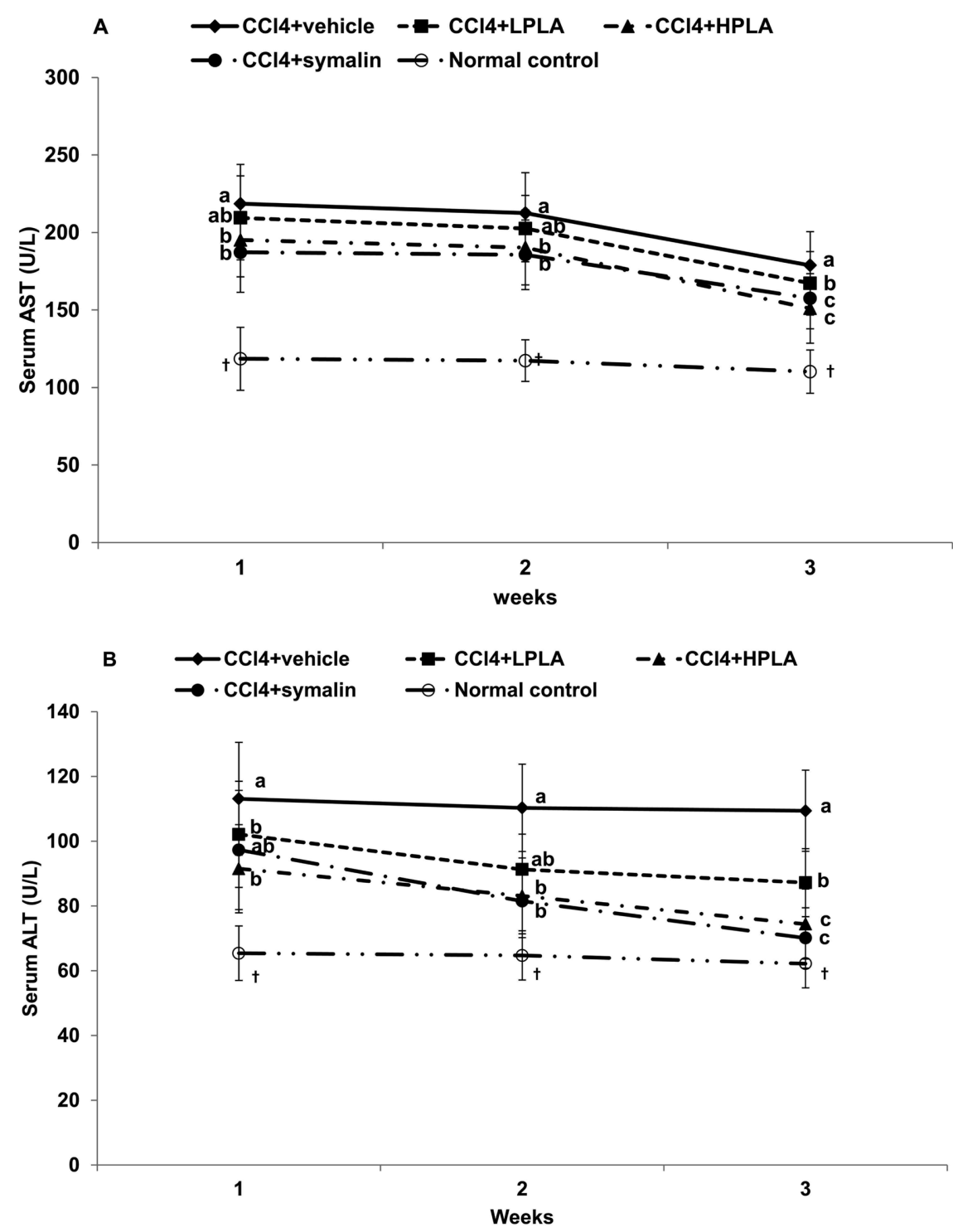

Fig. 2 Changes of serum ALT and AST levels during the experimental periods. Liver damage-induced rats by subcutaneously injecting BSP were orally administered with vehicle (saline dissolved with DMSO) for control group, 300 and $1000 \mathrm{mg}$ pig placental extracts/kg bw for low and high dosage groups, respectively, and $80 \mathrm{mg}$ silymarin $/ \mathrm{kg}$ bw for positive control in a daily basis. Normal rats were treated with vehicle as a normal-control group. Every week serum AST (A) and ALT (B) levels were measured in the blood from tail vein during the experimental periods. ${ }^{\mathrm{a}, \mathrm{b}} \mathrm{Means}$ with different superscripts were significantly different among $\mathrm{CCL}_{4}$-treated groups at $p<0.05$. ${ }^{\dagger}$ Significant difference between the control $\left(\mathrm{CCl}_{4}+\right.$ vehicle) group at $p<0.05$.

간 조직 형태 변화. 약물을 각 군에 맞게 3주 동안 투여한 후 에 간의 조직 형태 변화를 $\mathrm{H} \& \mathrm{E}$ 염색으로 조사하였을 때 정 상대조군에 비해 음성대조군에서 간세포의 변성이 증가하였고,
특히 지방양이 증가한 것을 볼 수 있었다(Fig. 3). 이러한 사염 화탄소 주입으로 인한 간 변성과 지방양의 증가는 silymarin과 돈태반군에서 농도 의존적으로 감소하였다. 


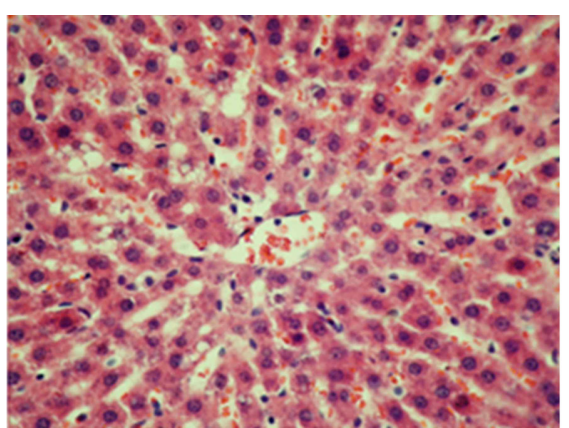

$\mathrm{CCl}_{4}+$ vehicle

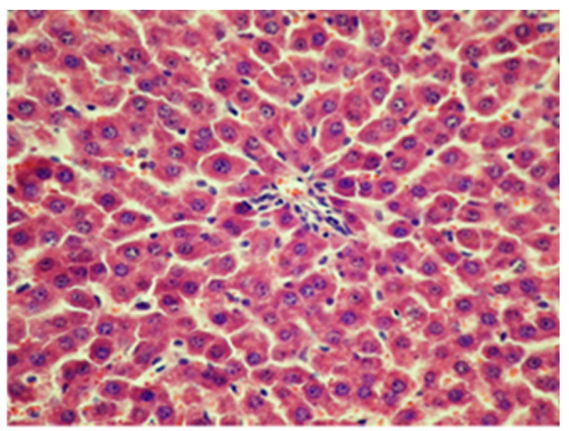

$\mathrm{CCl}_{4}+\mathrm{HPLA}$

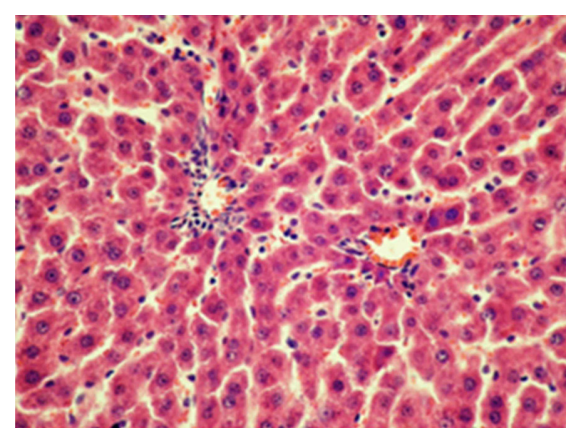

$\mathrm{CCl}_{4}+\mathrm{LPLA}$

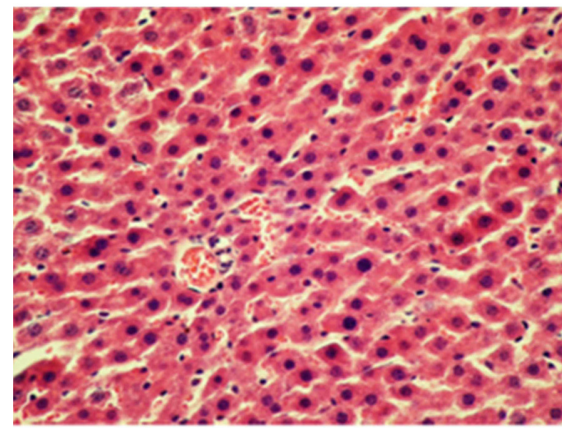

$\mathrm{CCl}_{4}+$ symaline

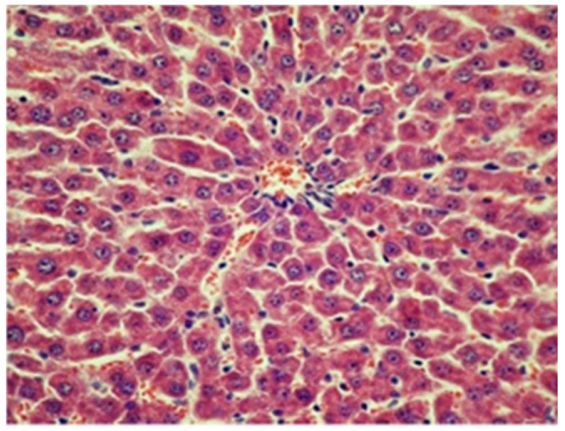

Normal control

Fig. 3 Liver morphometry. Liver damage-induced rats by subcutaneously injecting BSP were orally administered with vehicle (saline dissolved with DMSO) for control group, 300 and $1000 \mathrm{mg}$ pig placental extracts $/ \mathrm{kg}$ bw for low and high dosage groups, respectively, and $80 \mathrm{mg}$ silymarin/kg bw for positive control in a daily basis. Normal rats were treated with vehicle as a normal-control group. After 3 weeks of treatment, the liver morphometry was measured by hematoxylin $\&$ eosin staining.

\section{고 찰}

본 연구는 사염화탄소 주입으로 간 손상을 유발한 백서에서 돈 태반 가수분해물의 경구투여가 간 손상을 완화시키는지에 대한 연구를 하였다. 본 연구에서 간 독성을 유발하는데 사용한 사 염화탄소는 산업장에서 많이 발생하는 유해물질로 간 독성을 일 으키는 작용기전이 규명되어 있지 않으나 사염화탄소가 과산화 작용기전을 활성화시켜 간세포를 손상시킨다는 보고가 있다(Huo 등 2011; Jung 등, 2011; Makni 등 2011). 사염화탄소는 실험 동물에서 간세포 사멸, 섬유증 및 암을 유발시키는 물질로 간 손 상을 유발시키는데 많이 사용해 왔다. 사염화탄소가 간 세포를 손 상시키는 기전을 살펴보면 사염화탄소는 smooth endoplasmic reticulum에서 cytochrome $\mathrm{P} 450$ 에 의해 trichloromethyl free radical
$\left(\mathrm{CCl}_{3}\right)$ 로 전환되고 이것은 산소와 반응하여 $\mathrm{Cl}_{3} \mathrm{C}-\mathrm{O}-\mathrm{O}$ 를 형성 한다. $\mathrm{CCl}_{3}$ 와 $\mathrm{Cl}_{3} \mathrm{C}-\mathrm{O}-\mathrm{O}$ 는 $\mathrm{DNA}$ 와 지방산의 과산화를 촉진시켜 미토콘드리아막이나 세포막의 불포화지방산에 과산화 반응을 일 으켜 막의 구조와 기능을 손상시켜 간세포 사멸을 촉진한다(Huo 등 2011; Makni 등 2011; Koh 등, 2012). 또한, 사염화탄소로 간 손상을 유발시키면 단백질 합성, 글리코겐의 저장량을 감소 시키고 간세포 파괴로 인한 혈청 ALT와 AST 농도를 증가시킨 다는 보고가 있다(Huo 등 2011; Makni 등 2011). 또한, 조직 학적으로는 간세포의 응고괴사, 지방변성, 염증 증가, 수종 변 성 등을 나타낸다고 알려졌다. 그러므로 사염화탄소 주입으로 인한 간세포 손상을 저하시키기 위해서는 과산화반응이나 염증 을 억제하는 것이 필요하다. 본 연구에서도 정상대조군에 비해 사염화탄소를 주입한 음성대조군에서 체내 과산화정도를 나타 
Table 3 Serum triglyceride and cholesterol levels and liver triglyceride levels at the end of experiment

\begin{tabular}{|c|c|c|c|c|c|}
\hline & $\mathrm{CCl}_{4}+$ vehicle & $\mathrm{CCl}_{4}+\mathrm{LPLA}$ & $\mathrm{CCl}_{4}+\mathrm{HPLA}$ & $\mathrm{CCl}_{4}+$ symaline & Normal control \\
\hline Serum triglycerides $(\mathrm{mg} / \mathrm{dL})$ & $113.2 \pm 17.6^{\mathrm{a}}$ & $92.5 \pm 11.0^{\mathrm{b}}$ & $79.5 \pm 10.3^{\mathrm{c}}$ & $72.6 \pm 9.2^{\mathrm{c}}$ & $61.5 \pm 8.2^{\dagger}$ \\
\hline Serum total cholesterol (mg/dL) & $85.5 \pm 10.3^{\mathrm{a}}$ & $78.4 \pm 10.4^{\mathrm{ab}}$ & $71.3 \pm 9.1^{\mathrm{b}}$ & $63.8 \pm 8.9^{\mathrm{b}}$ & $70.8 \pm 9.1^{\dagger}$ \\
\hline Hepatic triglycerides (mg/g wet weight) & $3.31 \pm 0.72^{\mathrm{a}}$ & $2.56 \pm 0.66^{\mathrm{ab}}$ & $1.95 \pm 0.64^{\mathrm{b}}$ & $1.63 \pm 0.29^{\mathrm{b}}$ & $1.45 \pm 0.44^{\dagger}$ \\
\hline Hepatic total cholesterol (mg/g wet weight) & $2.30 \pm 0.57^{\mathrm{a}}$ & $1.85 \pm 0.48^{\mathrm{ab}}$ & $1.61 \pm 0.38^{\mathrm{b}}$ & $1.45 \pm 0.37^{\mathrm{b}}$ & $1.35 \pm 0.31^{\dagger}$ \\
\hline Hepatic lipid peroxides (TBARS) contents (nmol/mg protein) & $4.34 \pm 0.78^{\mathrm{a}}$ & $3.72 \pm 0.65^{\mathrm{ab}}$ & $3.15 \pm 0.53^{\mathrm{b}}$ & $3.07 \pm 0.58^{\mathrm{b}}$ & $2.12 \pm 0.53^{\dagger}$ \\
\hline
\end{tabular}

${ }^{\mathrm{a}, \mathrm{b}, \mathrm{c}}$ Means with different superscripts were significantly different among $\mathrm{CCL}_{4}$-treated groups at $p<0.05$.

${ }^{\dagger}$ Significant difference between the $\mathrm{CCl}_{4}+$ vehicle group at $p<0.05$.

내는 $\mathrm{TBARS}$ 의 함량이 간세포에서 높았으며 간에 저장된 중성 지방의 함량이 높았고, 혈청내 ALT와 AST의 농도도 증가하였 다. 또한, 간세포의 조직에서 괴사와 세포의 변형이 나타난 것 을 볼 수 있었다.

태반은 태아에게 영양 공급을 하기 위한 각종 영양소(각종 활성 펩타이드, 아미노산, 비타민, 미네랄, 수백 종의 효소 등) 가 이 조직에 집중 되어 있으며, 또한 많은 면역 강화 작용을 하는 물질이 생산, 비축되어 있다. 그래서 태반을 이용한 화장 품과 주사 등의 제품이 판매되고 있으나 아직까지 실제로 갱년 기나 간 보호 효과에 대한 연구는 적으며(Pal 등, 1995; Jung 등, 2011) 어떤 성분에 의한 효과인지에 대한 연구도 거의 없 었다. 본 연구에서는 이미 간 손상을 저하시키는 효과가 있다 고 알려진 silymarin 투여한 백서를 양성대조군으로 사용하였다. silymarin은 국화과(Compositae) 속의 엉겅퀴(Silybum marianum L. Gaerth)에 함유되어 있고, 그리스 로마 시대부터 간에 좋은 약초로 널리 사용되어 왔다. silymarin은 플라보노이드의 일종 으로 엉겅퀴의 유효성분으로 간 손상을 억제하는 기능이 있다 는 것이 보고되었다(Mansour 등, 2006; Al-Anati 등, 2009; Raškoviæ 등 2011). 실험동물에서 silymarin의 투여는 사염화탄 소 주입 후에 간에서 과산화물의 생성과 지방의 축적을 억제하 고 간세포의 파괴를 억제하여 혈청내 AST와 ALT의 농도의 상 승을 억제시키는 효과를 보였다(Mansour 등, 2006; Al-Anati 등, 2009; Rašković 등 2011). 또한, macrophage나 내피세포에 $50 \mathrm{iM}$ 의 silymarin의 처리는 혈청의 low-density lipoprotein (LDL) 산화를 억제하는 효과가 있다는 것도 보고되었다 (Skottova 등, 1999; Wallace 등, 2008). 결과적으로 세포와 동 물 실험에서 모두 silymarin은 사염화탄소의 주입으로 간 손상 을 유도하였을 때 이를 억제하는 효과가 있다는 것이 밝혀졌다. 본 연구에서도 과거의 연구와 유사하게 사염화탄소의 주입으로 간 손상을 유도한 백서에서 silymarin을 장기간 투여하였을 때 간에서 발생하는 과산화물과 지방의 축적량이 감소하였고, 혈청 내 $\mathrm{AST}$ 와 $\mathrm{ALT}$ 의 농도의 증가도 억제하였고 간 조직의 형태 변형도 감소시켰다.

본 연구에서는 사염화탄소로 간 손상을 유발시킨 백서에서 고용량 돈태반 가수분해물과 silymarin을 투여한 백서에서 유사 하게 간 손상을 억제하는 경향을 나타내었다. 이들의 작용기전 도 유사하여 간에서 발생하는 과산화물과 지방의 축적량이 감 소하였고, 혈청내 $\mathrm{AST}$ 와 $\mathrm{ALT}$ 의 농도의 증가도 억제하였고, 간 조직의 형태 변형도 감소시켰다. 그러나 본 연구에서의 제한점 은 돈태반 가수분해물의 어떤 성분이 간 손상을 억제하는 기능 이 있는 지에 대한 것을 밝히지는 못했다는 것이다. 돈태반에 는 다양한 성분의 영양소가 함유되어 있는데, 그 중에서도 여 성호르몬과 성장 호르몬 등의 다양한 호르몬이 함유되어 있는
데 일반적으로 돈태반 가수분해물을 제조하는 과정에서 기능을 소실하거나 제거될 가능성이 높다. 그러므로 간 손상을 억제하 는 유성성분은 아미노산을 비롯한 작은 화합물일 가능성이 높다.

\section{초 록}

본 연구의 목적은 간 손상을 유발시킨 백서에서 돈태반 가수분 해물의 경구 투여가 간 기능 개선에 효과가 있는 지를 조사하 는 것이다. 사염화탄소를 피하주사하여 간 손상을 유발한 백서 를 4군으로 나누어 $\mathrm{DMSO}$ (음성대조군), 저용량과 고용량( 500 과 $1000 \mathrm{mg} / \mathrm{kg}$ 체중) 돈태반 가수분해물, silymarin $(80 \mathrm{mg} / \mathrm{kg}$ 체중; 양성대조군)을 3 주간 경구 투여하였다. 정상대조군은 사염화탄 소 대신 용매인 옥수수 기름만을 피하주사하였다. 3주 후에 간 과 지라의 질량은 음성대조군에 비해 농도 의존적으로 돈태반 가수분해물과 silymarin 투여군이 더 높았다 $(p<0.05)$. 제거율을 계산하여 간의 기능을 나타내는 bromosulfalein (BSP)를 주입하 였을 때 간에서의 제거율은 음성대조군에 비해 돈태반 가수분 해물의 복용량에 비례해서 증가하였고, 특히 고용량 돈태반투여 군은 silymarin군과 유사한 값을 나타내었다. 이 결과 혈청내 $\mathrm{BSP}$ 농도는 돈태반투여군과 silymarin군에 비해 음성대조군에 서 더 낮았다. 모든 군에서 간 기능의 지표인 혈청 $\mathrm{AST}$ 와 ALT의 농도는 시간이 지남에 따라 감소하였는데, 돈태반 가수 분해물과 silymarin 투여는 음성대조군에 비해 큰 폭으로 감소 하였다. 간과 혈청내 중성지방과 콜레스테롤 농도 그리고 간세 포내의 지질 과산화물과 간 조직형태의 변형도 돈태반 가수분 해물의 농도에 비례해서 감소하였고, 고용량 돈태반군은 silymarin군 만큼 감소하였다. 결과적으로 사염화탄소에 의해서 간 손상을 유발시킨 백서에서 고용량의 돈태반 가수분해물 투 여가 간의 손상을 억제하는 효과가 있다고 결론지을 수 있다.

Keywords 간 손상 - 돈태반 가수분해물 - 사염화탄소 - 중성지방 bromosulfalein

감사의 글. 이 논문은 중소기업청에서 지원하는 2011년 산학연공동기술개발 사업에 의해서 수행되었습니다.

\section{참고문헌}

Abdel-Hameid NA (2007) Protective role of dimethyl diphenyl bicarboxylate (DDB) against erythromycin induced hepatotoxicity in male rats. Toxicol In Vitro 21, 618-25.

Al-Anati L, Essid E, Reinehr R, and Petzinger E (2009) Silibinin protects 
OTA-mediated TNF-alpha release from perfused rat livers and isolated rat Kupffer cells. Mol Nutr Food Res 53, 460-6.

Buege JA and Aust SD (1978) Microsomal lipid peroxidation. Methods Enzymol 52, 302-10.

Chen Y, Krishan M, Nebert DW, and Shertzer HG (2012) Glutathionedeficient mice are susceptible to TCDD-induced hepatocellular toxicity but resistant to steatosis. Chem Res Toxicol 25, 94-100.

Chiang DJ, Pritchard MT, and Nagy LE (2011) Obesity, diabetes mellitus, and liver fibrosis. Am J Physiol Gastrointest Liver Physiol 300, G697-702.

Huo HZ, Wang B, Liang YK, Bao YY, and Gu Y (2011) Hepatoprotective and Antioxidant Effects of Licorice Extract against $\mathrm{CCl}_{4}$ )-Induced Oxidative Damage in Rats. Int J Mol Sci 12, 6529-43.

Jo WS, Nam BH, Oh SJ, Choi YJ, Kang EY, Hong SH et al. (2008) Hepatic protective effect and single-dose toxicity study of water extract of Cordyceps militaris grown upon Protaetia dreujtarsis. Food Sci Biotech 40, $1-5$.

Jung J, Lee HJ, Lee JM, Na KH, Hwang SG, and Kim GJ (2011) Placenta extract promote liver regeneration in CCl4-injured liver rat model. Int Immuno pharmacol 11, 976-84.

Koh PH, Mokhtar RA, and Iqbal M (2012) Antioxidant potential of Cymbopogon citratus extract: alleviation of carbon tetrachloride-induced hepatic oxidative stress and toxicity. Hum Exp Toxicol 31, 81-91.

Korenaga M, Hidaka I, Nishina S, Sakai A, Shinozaki A, Gondo T et al. (2011) A glycyrrhizin-containing preparation reduces hepatic steatosis induced by hepatitis $\mathrm{C}$ virus protein and iron in mice. Liver Int 31, 55260 .

Liu KX, Kato Y, Kaku T, and Sugiyama Y (1998) Human placental extract stimulates liver regeneration in rats. Biol Pharm Bull 21, 44-9.
Makni M, Chtourou Y, Fetoui H, Garoui el M, Boudawara T, and Zeghal N (2011) Evaluation of the antioxidant, anti-inflammatory and hepatoprotective properties of vanillin in carbon tetrachloride-treated rats. Eur J Pharmacol 668, 133-9.

Mansour HH, Hafez HF, and Fahmy NM (2006) Silymarin Modulates Cisplatin-Induced Oxidative Stress and Hepatotoxicity in Rats. Biochem Mol Biol Rep 39, 656-61.

Pal P, Roy R, Datta PK, Dutta AK, Biswas B, and Bhadra R (1995) Hydroalcoholic human placental extract: skin pigmenting activity and gross chemical composition. Int J Dermatol 34, 61-6.

Raškoviæ A, Stilinoviæ N, Kolaroviæ J, Vasoviæ V, Vukmiroviæ S, and Mikov M (2011) The protective effects of silymarin against doxorubicininduced cardiotoxicity and hepatotoxicity in rats. Molecules 16, 8601-13.

Richmond W (1976) Use of cholesterol oxidase for assay of total and free cholesterol in serum by continuous flow analysis. Clin Chem 2, 1579-88.

Sebokova E, Klimes I, Moss R, Stolba P, Wiersma MM, and Mitková A (1993) Muscle GLUT 4 protein levels and impaired triglyceride metabolism in streptozotocin diabetic rats. Effect of a high sucrose diet and fish oil supplementation. Ann NY Acad Sci 683, 218-27.

Skottova N, Krecman V, and Simanek V (1999) Activities of silymarin and its flavonolignans upon low density lipoprotein oxidizability in vitro. Phytother Res 13, 535-7.

Wallace S, Vaughn K, Stewart BW, Viswanathan T, Clausen E, and Nagarajan S (2008) Milk thistle extracts inhibit the oxidation of low-density lipoprotein (LDL) and subsequent scavenger receptor-dependent monocyte adhesion. J Agric Food Chem 56, 3966-72.

West HJ (1989) Clearance of bromosulphthalein by the liver of sheep. Res Vet Sci 46, 258-63. 